\title{
Medical Expenditures Attributed to Asthma and Chronic Obstructive Pulmonary Disease Among Workers — United States, 2011-2015
}

\author{
Girija Syamlal, MBBS ${ }^{1}$; Anasua Bhattacharya, $\mathrm{PhD}^{2}$; Katelynn E. Dodd, $\mathrm{MPH}^{1}$
}

Asthma and chronic obstructive pulmonary disease (COPD) are respiratory conditions associated with a significant economic cost among U.S. adults $(1,2)$, and up to $44 \%$ of asthma and $50 \%$ of COPD cases among adults are associated with workplace exposures (3). CDC analyzed 2011-2015 Medical Expenditure Panel Survey (MEPS) data to determine the medical expenditures attributed to treatment of asthma and COPD among U.S. workers aged $\geq 18$ years who were employed at any time during the survey year. During 2011-2015, among the estimated 166 million U.S. workers, 8 million had at least one asthma-related medical event, ${ }^{*}$ and 7 million had at least one COPD-related medical event. The annualized total medical expenditures, in 2017 dollars, were $\$ 7$ billion for asthma and $\$ 5$ billion for COPD. Private health insurance paid for $61 \%$ of expenditures attributable to treatment of asthma and 59\% related to COPD. By type of medical event, the highest annualized per-person asthma- and COPD-related expenditures were for inpatient visits: $\$ 8,238$ for asthma and $\$ 27,597$ for COPD. By industry group, the highest annualized per-person expenditures $(\$ 1,279$ for asthma and $\$ 1,819$ for COPD) were among workers in public administration. Early identification and reduction of risk factors, including workplace exposures, and implementation of proven interventions are needed to reduce the adverse health and economic impacts of asthma and COPD among workers.

MEPS is an annual household survey administered to a nationally representative sample of the noninstitutionalized civilian U.S. population through an in-person interview. ${ }^{\dagger}$ During the study period, 2011-2015, the years with the most recent available data, the annual survey response rates ranged from $54.9 \%$ in 2011 to $47.7 \%$ in 2015 . To improve the precision and reliability of estimates, 2011-2015 data were combined.

\footnotetext{
* Hospital inpatient care, outpatient visits, emergency department visits, officebased visits, home health care, or purchase of prescribed medicines.

${ }^{\dagger}$ https://meps.ahrq.gov/mepsweb/survey_comp/household.jsp.
}

Participants' self-reported information on medical conditions, the associated medical events, payments, source of payments, and employment status were collected during the MEPS interview. MEPS professional coders assigned a code to

\section{INSIDE}

815 Salmonellosis Outbreak Detected by Automated Spatiotemporal Analysis - New York City, MayJune 2019

820 Use of Molecular Epidemiology to Inform Response to a Hepatitis A Outbreak — Los Angeles County, California, October 2018-April 2019

825 Screening for SARS-CoV-2 Infection Within a Psychiatric Hospital and Considerations for Limiting Transmission Within Residential Psychiatric Facilities - Wyoming, 2020

830 COVID-19 Outbreak Among College Students After a Spring Break Trip to Mexico - Austin, Texas, March 26-April 5, 2020

836 Serial Laboratory Testing for SARS-CoV-2 Infection Among Incarcerated and Detained Persons in a Correctional and Detention Facility - Louisiana, April-May 2020

841 Characteristics of Adult Outpatients and Inpatients with COVID-19 - 11 Academic Medical Centers, United States, March-May 2020

847 Exposures Before Issuance of Stay-at-Home Orders Among Persons with Laboratory-Confirmed COVID-19 - Colorado, March 2020

850 QuickStats

Continuing Education examination available at https://www.cdc.gov/mmwr/mmwr_continuingEducation.html

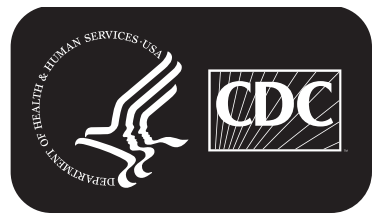


the medical condition or conditions associated with each medical event reported by the participant, using the International Classification of Diseases, Ninth Revision, Clinical Modification (ICD-9-CM). Each medical event could be assigned one or more ICD-9-CM codes. Medical events associated with treated asthma were identified using ICD-9-CM code 493 and medical events associated with treated COPD were identified using ICD-9-CM codes 490, 491, 492, and 496. $\$$

Expenditures were calculated from the sum of payments from Medicaid, Medicare, private insurance, out-of-pocket expenses, and other sources for each treated asthma- and COPD-associated medical event. The annualized, total and per-person unadjusted medical expenditures for workers with asthma and COPD were estimated by type of medical event and source of payments. Workers were those who were "currently employed," "had no job at the interview date but had a job to return to" or were employed at any time during the survey year. Information on participants' current industry was categorized into 15 industry groups.**

\footnotetext{
${ }^{\S}$ https://meps.ahrq.gov/data_stats/download_data/pufs/h180/h180doc.pdf.

9 Veterans Administration/CHAMPVA, TRICARE, and other federal sources include Indian Health Service, military treatment facilities, and other care by the federal government. Other state and local sources include community and neighborhood clinics, state and local health departments, and state programs other than Medicaid, and workers' compensation. Other unclassified sources include sources such as automobile, homeowner's, and liability insurance and other miscellaneous or unknown sources.

** https://meps.ahrq.gov/data_stats/download_data/pufs/ind_occ/ind3.pdf.
}

Data were weighted to produce nationally representative estimates using sample weights adjusted for the 5-year data. Data were analyzed using SAS software (version 9.4; SAS Institute) to account for the complex survey design. Estimates with relative standard error (standard error of the estimate divided by the estimate) $\geq 30 \%$ are not reported. All expenditure values were expressed in 2017 U.S. dollars using the Medical Care Consumer Price Index. ${ }^{\dagger \dagger}$

During 2011-2015, among the annual average estimated 166 million U.S. persons aged $\geq 18$ years who were working at any time during the survey year, 8 million (5\%) workers had at least one asthma-related medical event, and 7 million (4\%) had at least one COPD-related medical event, which accounted for 21 million asthma-associated and 15 million COPD-related medical events (Table 1). The proportion of current smokers among workers who had an asthma event during the study period was $13 \% ; 24 \%$ had a COPD event. Annualized average per-person medical expenditures attributable to treated asthma and COPD were $\$ 901$ and $\$ 681$, respectively. Highest annualized expenditures per person attributable to treated asthma and treated COPD were among non-Hispanic whites $(\$ 923$ and $\$ 742$, respectively), persons with health insurance (\$914 and $\$ 705$, respectively), and current nonsmokers (\$936 and \$692, respectively). By age group, annualized per-person expenditures

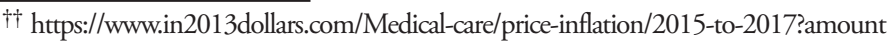

The MMWR series of publications is published by the Center for Surveillance, Epidemiology, and Laboratory Services, Centers for Disease Control and Prevention (CDC), U.S. Department of Health and Human Services, Atlanta, GA 30329-4027.

Suggested citation: [Author names; first three, then et al., if more than six.] [Report title]. MMWR Morb Mortal Wkly Rep 2020;69:[inclusive page numbers].

Centers for Disease Control and Prevention

Robert R. Redfield, MD, Director

Anne Schuchat, MD, Principal Deputy Director

Chesley L. Richards, MD, MPH, Deputy Director for Public Health Science and Surveillance

Rebecca Bunnell, PhD, MEd, Director, Office of Science

Arlene Greenspan, PhD, Acting Director, Office of Science Quality, Office of Science

Michael F. Iademarco, MD, MPH, Director, Center for Surveillance, Epidemiology, and Laboratory Services

MMWR Editorial and Production Staff (Weekly)

Charlotte K. Kent, PhD, MPH, Editor in Chief Jacqueline Gindler, MD, Editor

Paul Z. Siegel, MD, MPH, Guest Associate Editor

Mary Dott, MD, MPH, Online Editor

Terisa F. Rutledge, Managing Editor

Douglas W. Weatherwax, Lead Technical Writer-Editor

Glenn Damon, Soumya Dunworth, PhD,

Teresa M. Hood, MS, Donald G. Meadows, MA Technical Writer-Editors

Michelle E. Bonds, MBA

Matthew L. Boulton, MD, MPH

Carolyn Brooks, ScD, MA

Jay C. Butler, MD

Virginia A. Caine, MD
Martha F. Boyd, Lead Visual Information Specialist

Maureen A. Leahy, Julia C. Martinroe, Stephen R. Spriggs, Tong Yang, Visual Information Specialists

Quang M. Doan, MBA, Phyllis H. King, Terraye M. Starr, Moua Yang, Information Technology Specialists

MMWR Editorial Board

Timothy F. Jones, MD, Chairman

Katherine Lyon Daniel, PhD

Jonathan E. Fielding, MD, MPH, MBA

David W. Fleming, MD

William E. Halperin, MD, DrPH, MPH

Jewel Mullen, MD, MPH, MPA Jeff Niederdeppe, PhD

\author{
Patricia Quinlisk, MD, MPH \\ Patrick L. Remington, MD, MPH \\ Carlos Roig, MS, MA \\ William Schaffner, MD \\ Morgan Bobb Swanson, BS
}


TABLE 1. Estimated number of workers with an asthma-related or chronic obstructive pulmonary disease-related medical event and annualized total and per-person expenditures, ${ }^{*}$ by selected characteristics among workers aged $\geq 18$ years - Medical Expenditure Panel Survey, United States, 2011-2015

\begin{tabular}{|c|c|c|c|c|c|c|c|}
\hline \multirow[b]{2}{*}{ Characteristic $^{\dagger}$} & \multirow[b]{2}{*}{$\begin{array}{l}\text { No. of workers } \\
(x 1,000)\end{array}$} & \multicolumn{3}{|c|}{ Asthma } & \multicolumn{3}{|c|}{ Chronic obstructive pulmonary disease } \\
\hline & & $\begin{array}{l}\text { No. of workers with } \\
\text { an event } \\
(x 1,000)\end{array}$ & $\begin{array}{c}\text { Total } \\
\text { expenditures } \\
\text { (\$) in millions }\end{array}$ & $\begin{array}{c}\text { Average } \\
\text { expenditure } \\
\text { (\$) per person }\end{array}$ & $\begin{array}{l}\text { No. of workers } \\
\text { with an event } \\
(x 1,000)\end{array}$ & $\begin{array}{c}\text { Total } \\
\text { expenditures } \\
\text { (\$) in millions }\end{array}$ & $\begin{array}{c}\text { Average } \\
\text { expenditure } \\
\text { (\$) per person }\end{array}$ \\
\hline Total & 166,347 & 7,920 & 7,137 & 901 & 7,371 & 5,021 & 681 \\
\hline \multicolumn{8}{|l|}{ Age group (yrs) } \\
\hline $18-34$ & 21,704 & 1,012 & 626 & 619 & 499 & 93 & 186 \\
\hline $35-44$ & 70,773 & 2,961 & 2,268 & 766 & 2,421 & 515 & 213 \\
\hline $45-64$ & 63,467 & 3,375 & 3,648 & 1,081 & 3,568 & 3,355 & 940 \\
\hline$\geq 65$ & 10,403 & 659 & 595 & 903 & 971 & 1,058 & 1,090 \\
\hline \multicolumn{8}{|l|}{ Sex } \\
\hline Men & 86,749 & 2,954 & 2,473 & 837 & 3,057 & 2,238 & 732 \\
\hline Women & 79,598 & 5,053 & 4,663 & 923 & 4,403 & 2,783 & 632 \\
\hline \multicolumn{8}{|l|}{ Race/Ethnicity } \\
\hline Hispanic & 26,499 & 891 & 745 & 836 & 594 & 129 & 217 \\
\hline White, non-Hispanic & 107,676 & 5,564 & 5,140 & 923 & 5,865 & 4,350 & 742 \\
\hline Black, non-Hispanic & 18,712 & 1,037 & 879 & 847 & 613 & 375 & 611 \\
\hline Other & 13,460 & 515 & 372 & 722 & 388 & 168 & 433 \\
\hline \multicolumn{8}{|l|}{ Household income } \\
\hline$<\$ 35,000$ & 39,521 & 1,794 & 1,520 & 847 & 1,810 & 1,091 & 603 \\
\hline$\$ 35,000-\$ 74,999$ & 53,373 & 2,486 & 2,112 & 850 & 2,579 & 2,113 & 819 \\
\hline$\geq \$ 75,000$ & 73,375 & 3,726 & 3,505 & 940 & 3,070 & 1,817 & 592 \\
\hline \multicolumn{8}{|l|}{ Education } \\
\hline $\begin{array}{l}\text { Less than high } \\
\text { school }\end{array}$ & 67,266 & 2,396 & 2,185 & 911 & 2,961 & 2,838 & 959 \\
\hline High school or more & 98,269 & 5,607 & 4,951 & 883 & 4,468 & 2,170 & 486 \\
\hline \multicolumn{8}{|l|}{ Insurance coverage } \\
\hline Yes & 142,396 & 7,509 & 6,866 & 914 & 6,916 & 4,875 & 705 \\
\hline No & 23,951 & 498 & 270 & 542 & 544 & 146 & 268 \\
\hline \multicolumn{8}{|l|}{ U.S. Census region $\$$} \\
\hline Northeast & 29,696 & 1,851 & 1,787 & 965 & 1,281 & 984 & 768 \\
\hline Midwest & 36,660 & 1,757 & 1,621 & 923 & 1,941 & 1,757 & 905 \\
\hline South & 60,870 & 2,683 & 2,381 & 887 & 2,826 & 1,117 & 395 \\
\hline West & 38,809 & 1,714 & 1,348 & 787 & 1,408 & 1,162 & 825 \\
\hline \multicolumn{8}{|c|}{ Current smoking status ${ }^{\pi}$} \\
\hline Smoker & 24,820 & 955 & 664 & 695 & 1,636 & 1,024 & 626 \\
\hline Nonsmoker & 125,570 & 6,514 & 6,097 & 936 & 5,220 & 3,612 & 692 \\
\hline
\end{tabular}

* All medical expenditures expressed in 2017 U.S. dollars.

† Missing information on education for 812,000; on household income for 78,000; on region for 312,000; and on smoking status for 15,957,000 workers. Columns do not sum to totals because of rounding; those with missing values were excluded from the analysis.

$\S$ https://www2.census.gov/geo/pdfs/maps-data/maps/reference/us_regdiv.pdf.

"Based on yes/no responses to the question "Do you currently smoke?"

for asthma and COPD were highest among persons aged $45-64$ years $(\$ 1,081) \geq 65$ years $(\$ 1,090)$, respectively.

Prescription medication accounted for the highest number of events for asthma ( 15 million) and for COPD (8 million) (Table 2). The total annualized medical expenditures for treated asthma-related medical events among workers were $\$ 7$ billion, and they were $\$ 5$ billion for COPD. Derived using the pooled population-attributable fraction of $16 \%$ for asthma and 14\% for COPD (3), annualized expenditures attributable to workplace exposures exceeded $\$ 1$ billion for asthma and $\$ 700$ million for COPD.

By type of medical event, prescription drugs for asthma ( $\$ 5$ billion) and inpatient visits for COPD ( $\$ 2$ billion) accounted for the highest total annualized expenditures. Annualized expenditures per person were highest for inpatient visits (excluding prescription medications): $\$ 8,238$ for asthma and $\$ 27,597$ for COPD. By source of payment, private health insurance paid for $61 \%$ ( $\$ 4$ billion) of expenditures attributable to treated asthma and 59\% ( $\$ 3$ billion) of expenditures attributable to treated COPD. The highest annualized expenditures per person were paid by private insurance for asthma $(\$ 811)$ and Medicare for COPD (\$983).

Among industry groups, the annualized expenditures per person for treated asthma were highest among public administration workers $(\$ 1,279)$, followed by transportation and utilities workers $(\$ 1,222)$ (Table 3). The annualized expenditures 
TABLE 2. Estimated number of workers with asthma-related or chronic obstructive pulmonary disease-related medical event and annualized total and per-person expenditures, ${ }^{*}$ by type of event and source of payment - Medical Expenditure Panel Survey, United States, 2011-2015

\begin{tabular}{|c|c|c|c|c|c|c|c|c|}
\hline \multirow[b]{2}{*}{$\begin{array}{l}\text { Event/Source of } \\
\text { payment }^{\dagger}\end{array}$} & \multicolumn{4}{|c|}{ Asthma } & \multicolumn{4}{|c|}{ Chronic obstructive pulmonary disease } \\
\hline & $\begin{array}{c}\text { Total } \\
\text { no. of events }\end{array}$ & $\begin{array}{c}\text { No. of workers } \\
\text { with an event } \\
(x 1,000)\end{array}$ & $\begin{array}{c}\text { Total } \\
\text { expenditures } \\
\text { (\$) in millions }\end{array}$ & $\begin{array}{c}\text { Average } \\
\text { expenditure } \\
\text { (\$) per person }\end{array}$ & $\begin{array}{c}\text { Total } \\
\text { no. of events }\end{array}$ & $\begin{array}{l}\text { No. of workers } \\
\text { with an event } \\
(x 1,000)\end{array}$ & $\begin{array}{c}\text { Total } \\
\text { expenditures } \\
\text { (\$) in millions }\end{array}$ & $\begin{array}{c}\text { Average } \\
\text { expenditure } \\
\text { (\$) per person }\end{array}$ \\
\hline Total $^{\S}$ & 21,206 & 7,920 & 7,137 & 901 & 14,540 & 7,371 & 5,021 & 681 \\
\hline \multicolumn{9}{|l|}{ Type of event } \\
\hline $\begin{array}{l}\text { Prescription } \\
\text { drugs }\end{array}$ & 15,008 & 5,361 & 5,216 & 973 & 8,421 & 3,733 & 1,627 & 436 \\
\hline $\begin{array}{l}\text { Office based } \\
\text { visits }\end{array}$ & 5,503 & 2,117 & 921 & 435 & 5,262 & 3,064 & 1,041 & 340 \\
\hline Inpatient visits & 66 & 63 & 519 & 8,238 & 71 & 62 & 1,711 & 27,597 \\
\hline $\begin{array}{l}\text { Emergency } \\
\text { department } \\
\text { visits }\end{array}$ & 412 & 332 & 372 & 1,121 & 441 & 375 & 442 & 1,178 \\
\hline Outpatient visits & 210 & 126 & 106 & 841 & 293 & 205 & 166 & 810 \\
\hline $\begin{array}{l}\text { Home health } \\
\text { visits }\end{array}$ & 8 & 8 & 3 & 375 & 52 & 21 & 35 & 1,667 \\
\hline \multicolumn{9}{|c|}{ Source of payment } \\
\hline Private insurance & 16,917 & 5,331 & 4,326 & 811 & 9,235 & 4,173 & 2,949 & 707 \\
\hline Out of pocket? & 22,907 & 6,673 & 1,370 & 205 & 14,489 & 5,993 & 664 & 111 \\
\hline Medicaid & 3,011 & 977 & 681 & 697 & 1,859 & 647 & 391 & 604 \\
\hline Medicare & 2,473 & 635 & 446 & 702 & 2,399 & 775 & 761 & 983 \\
\hline Other** & 2,109 & 583 & 314 & 556 & 1,437 & 592 & 256 & 432 \\
\hline
\end{tabular}

${ }^{*}$ All medical expenditures expressed in 2017 U.S. dollars.

+ More than one type of medical event and source of payment could be reported per person.

$\S$ Columns do not sum to totals because of rounding.

I Portion of total payments made by persons or families for services received during the year, including deductibles, coinsurance, and copayments for covered services plus all expenditures for services not covered by the insurance.

** Includes payments from the Department of Veterans Affairs (excluding TRICARE); other federal sources (Indian Health Service, military treatment facilities, and other care provided by the Federal Government); various state and local sources (community and neighborhood clinics, state and local health departments, and State programs other than Medicaid); payments from Workers' Compensation; and, other unclassified sources (e.g., automobile, homeowner's, or liability insurance, and other miscellaneous or unknown sources). It also includes private insurance payments reported for persons without private health insurance coverage during the year, as defined in the Medical Expenditure Panel Survey, and Medicaid payments reported for persons who were not enrolled in the Medicaid program at any time during the year (https://meps.ahrq.gov/mepstrends/hc_cond/).

per person for treated COPD were highest among public administration workers $(\$ 1,819)$, followed by construction workers $(\$ 1,198)$.

\section{Discussion}

COPD and asthma combined were among the top five most costly medical conditions among U.S. adults in 2012 (4). Among workers, the total medical expenditures attributable to the treatment of asthma and COPD were substantial ( $\$ 7$ billion for asthma and \$5 billion for COPD) and varied by sociodemographic characteristics and industry. Workers in the public administration industry (e.g., police officers, correctional officers, jailers, firefighters, and secretaries and administrative assistants) ${ }^{\$ \$}$ had the highest annualized perperson expenditures for both asthma and COPD. In the public administration industry, an estimated $7.4 \%$ of workers have asthma, and $3.5 \%$ of workers have COPD. 99 Variation

\footnotetext{
$\$ \$$ https://datausa.io/profile/naics/92/.

99 https://wwwn.cdc.gov/eWorld/Set/Work-Related_Respiratory_Diseases/88; https://www.cdc.gov/mmwr/volumes/67/wr/mm6713a1.htm.
}

in expenditures by industry might reflect the differences in prevalences, health insurance status, and access to medical care. Overall, workers with no health insurance had lower medical expenditures for asthma and for COPD than did those who had health insurance, suggesting that the uninsured population might have sought services through free clinics or might have limited their care-seeking $(1,3)$. Based on the 2019 pooled population attributable fraction estimates of $16 \%$ for asthma and $14 \%$ for COPD, the estimated expenditures attributable to workplace exposures among workers exceeded $\$ 1$ billion for asthma and \$700 million for COPD.

Among workers, prescription medications accounted for the highest proportion of total medical expenditures attributable to the treatment of asthma, as did inpatient visits for the treatment of COPD, similar to previous findings among all U.S. adults $(1,5)$. Inpatient visits accounted for the highest per-person expenditure for treated asthma and COPD. Higher expenditures related to inpatient visits have been highly correlated with asthma and COPD exacerbation severity $(5,6)$. An estimated $67 \%$ of total asthma-attributable medical expenditures were 
TABLE 3. Estimated number of workers with an asthma-related or chronic obstructive pulmonary disease-related medical event and annualized total and per-person expenditures, ${ }^{*}$ by industry groups among workers aged $\geq 18$ years payment — Medical Expenditure Panel Survey, United States, 2011-2015

\begin{tabular}{|c|c|c|c|c|c|c|c|}
\hline \multirow[b]{2}{*}{ Industry group } & \multirow[b]{2}{*}{$\begin{array}{l}\text { No. of workers } \\
(x 1,000)\end{array}$} & \multicolumn{3}{|c|}{ Asthma } & \multicolumn{3}{|c|}{ Chronic obstructive pulmonary disease } \\
\hline & & $\begin{array}{l}\text { No. of workers } \\
\text { with an event } \\
(x 1,000)\end{array}$ & $\begin{array}{c}\text { Total } \\
\text { expenditures } \\
\text { (\$) in millions }\end{array}$ & $\begin{array}{c}\text { Average } \\
\text { expenditure } \\
\text { (\$) per person }\end{array}$ & $\begin{array}{l}\text { No. of workers } \\
\text { with an event } \\
(x 1,000)\end{array}$ & $\begin{array}{c}\text { Total } \\
\text { expenditures } \\
\text { (\$) in millions }\end{array}$ & $\begin{array}{c}\text { Average } \\
\text { expenditure } \\
\text { (\$) per person }\end{array}$ \\
\hline Natural resources & 2,320 & 57 & 47 & 825 & 96 & 36 & 375 \\
\hline Mining & 792 & 40 & 46 & 1,150 & $-^{\dagger}$ & - & - \\
\hline Construction & 10,500 & 221 & 214 & 968 & 344 & 412 & 1,198 \\
\hline Manufacturing & 16,354 & 658 & 733 & 1,114 & 874 & 614 & 703 \\
\hline Wholesale and retail trade & 21,400 & 1,005 & 940 & 935 & 821 & 404 & 492 \\
\hline Transportation and utilities & 7,771 & 284 & 347 & 1,222 & 349 & 155 & 444 \\
\hline Information & 3,306 & 155 & 136 & 877 & 137 & 76 & 555 \\
\hline Financial activities & 10,142 & 435 & 363 & 834 & 416 & 180 & 433 \\
\hline $\begin{array}{l}\text { Professional and business } \\
\text { services }\end{array}$ & 19,592 & 957 & 773 & 808 & 806 & 327 & 406 \\
\hline $\begin{array}{l}\text { Education health and social } \\
\text { services }^{\S}\end{array}$ & 38,507 & 2,421 & 2,250 & 929 & 2,004 & 1,435 & 716 \\
\hline Leisure and hospitality & 14,492 & 691 & 555 & 803 & 552 & 383 & 694 \\
\hline Other services & 8,515 & 363 & 324 & 893 & 398 & 199 & 500 \\
\hline Public administration ${ }^{\S}$ & 8,247 & 535 & 684 & 1,279 & 469 & 853 & 1,819 \\
\hline Military & 355 & - & - & - & - & - & - \\
\hline Unclassifiable/Missing & 4,054 & - & - & - & - & - & - \\
\hline
\end{tabular}

* All medical expenditures expressed in 2017 U.S. dollars.

† Unreliable estimates (relative standard error (RSE) >30; standard error of the estimate divided by the estimate), data suppressed.

$\S$ Includes education services workers and ambulatory healthcare services workers, hospitals, nursing and residential care facility workers and social assistance.

$\S$ https://datausa.io/profile/naics/92.

" Other services industries include repair and maintenance, personal and laundry services, religious, grantmaking, civic, professional services, and private households and similar organizations.

\section{Summary}

What is already known about this topic?

Asthma and chronic obstructive pulmonary disease (COPD) are associated with substantial economic and health costs among U.S. workers.

What is added by this report?

During 2011-2015, total annualized medical expenditures among U.S. workers were $\$ 7$ billion ( $\$ 901$ per person) for asthma and $\$ 5$ billion ( $\$ 681$ per person) for COPD. Inpatient visits were associated with the highest average per-person expenditures for both conditions. Insured workers incurred higher expenditures than did uninsured workers.

What are the implications for public health practice?

Early identification and reduction of risk factors, including workplace exposures (e.g., vapors, gas, dusts, and fumes), and implementation of proven interventions are needed to reduce the adverse health and economic impacts of asthma and COPD among workers.

associated with prescription medications, which is higher than the $51 \%$ observed previously among all U.S. adults (1). The higher prescription medication expenditures might be associated with new and more costly treatment options or could be a result of inflation adjustments $(1,7,8)$. Moreover, workers are more likely to have health insurance than are nonworkers (9); therefore, they might have fewer financial barriers to purchasing prescription medications, which might also partially explain the higher expenditures among workers.

The findings in this report are subject to at least four limitations. First, the number of medical events and expenditures associated with asthma and COPD were self-reported by respondents and might be subject to recall bias. However, self-reported medical events and expenditure data, including office-based visits, emergency department visits, and hospitalizations, have been shown to correspond well with health care utilization data (10). Second, workers could have been treated for comorbidities during their asthma- or COPDrelated medical encounter; therefore, a portion of medical expenditures might not be directly associated with asthma or COPD. Third, workers might have changed employment from the industry in which they were employed at the time of their asthma- or COPD-related medical events; therefore, medical expenditures by industry group might not reflect the actual industry the worker was employed in when the expenditure was incurred. Finally, small sample sizes for some groups resulted in unreliable estimates.

Annualized overall and per-person medical expenditures attributable to treated asthma and treated COPD among workers were substantial. Early identification and reduction of risk factors, including workplace exposures (e.g., vapors dusts gas and fumes), and implementation of proven interventions are needed to reduce the adverse health and economic impacts 
of asthma and COPD among workers. Prioritizing intervention efforts aimed at preventing asthma and COPD among workers, especially among those with higher medical costs, by supporting workplace programs and policies (e.g., smoke-free workplace policies, smoking cessation programs, and workplace exposure control measures) can reduce the impact of disease and improve worker health. ${ }^{* *}$ Continued surveillance is important to identify workers with high prevalences of asthma or COPD and less consistent access to health care.

\footnotetext{
*** https://goldcopd.org/wp-content/uploads/2018/11/GOLD-2019-v1.7FINAL-14Nov2018-WMS.pdf; https://ginasthma.org/wp-content/ uploads/2019/06/GINA-2019-main-report-June-2019-wms.pdf.
}

\section{Acknowledgments}

Laura Kurth, Respiratory Health Division, National Institute for Occupational Safety and Health, CDC; Tim Bushnell, Office of the Director, National Institute for Occupational Safety and Health, CDC.

Corresponding author: Girija Syamlal, gos2@cdc.gov, 304-285-5827.

${ }^{1}$ Respiratory Health Division, National Institute for Occupational Safety and Health, CDC; ${ }^{2}$ Office of the Director, National Institute for Occupational Safety and Health, CDC.

All authors have completed and submitted the International Committee of Medical Journal Editors form for disclosure of potential conflicts of interest. No potential conflicts of interest were disclosed.

\section{References}

1. Nurmagambetov T, Kuwahara R, Garbe P. The economic burden of asthma in the United States, 2008-2013. Ann Am Thorac Soc 2018;15:348-56. https://doi.org/10.1513/AnnalsATS.201703-259OC

2. Ford ES, Murphy LB, Khavjou O, Giles WH, Holt JB, Croft JB. Total and state-specific medical and absenteeism costs of COPD among adults aged $\geq 18$ years in the United States for 2010 and projections through 2020. Chest 2015;147:31-45. https://doi.org/10.1378/chest.14-0972

3. Blanc PD, Annesi-Maesano I, Balmes JR, et al. The occupational burden of non-malignant respiratory diseases. An official American Thoracic Society and European Respiratory Society Statement. Am J Respir Crit Care Med 2019;199:1312-34. https://doi.org/10.1164/rccm.201904-0717ST

4. Cohen S. Statistical brief \#455: the concentration of health care expenditures and related expenses for costly medical conditions, 2012. Rockville, MD: US Department of Health and Human Services, Agency for Healthcare Research and Quality; 2014. https://meps.ahrq.gov/ data_files/publications/st455/stat455.pdf

5. Toy EL, Gallagher KF, Stanley EL, Swensen AR, Duh MS. The economic impact of exacerbations of chronic obstructive pulmonary disease and exacerbation definition: a review. COPD 2010;7:214-28. https://doi. org/10.3109/15412555.2010.481697

6. Ivanova JI, Bergman R, Birnbaum HG, Colice GL, Silverman RA, McLaurin K. Effect of asthma exacerbations on health care costs among asthmatic patients with moderate and severe persistent asthma. J Allergy Clin Immunol 2012;129:1229-35. https://doi.org/10.1016/j. jaci.2012.01.039

7. Ehteshami-Afshar S, FitzGerald JM, Doyle-Waters MM, Sadatsafavi M. The global economic burden of asthma and chronic obstructive pulmonary disease. Int J Tuberc Lung Dis 2016;20:11-23. https://doi. org/10.5588/ijtld.15.0472

8. Guarascio AJ, Ray SM, Finch CK, SelfTH. The clinical and economic burden of chronic obstructive pulmonary disease in the USA. Clinicoecon Outcomes Res 2013;5:235-45.

9. Okoro CA, Zhao G, Fox JB, Eke PI, Greenlund KJ, Town M. Surveillance for health care access and health services use, adults aged 18-64 years-Behavioral Risk Factor Surveillance System, United States, 2014. MMWR Mortal Wkly Rep 2017;66(No. SS-7). https://oi.org/10.15585/mmwr.ss6607a1

10. Short ME, Goetzel RZ, Pei X, et al. How accurate are self-reports? Analysis of self-reported health care utilization and absence when compared with administrative data. J Occup Environ Med 2009;51:786-96. https://doi.org/10.1097/JOM.0b013e3181a86671 